\title{
Meyve ve Sebze Kabuklarının Fitokimyasal ve Antioksidan Özelliklerinin İncelenmesi
}

\author{
Investigation of Phytochemical and Antioxidant Properties of Fruit and Vegetable Peels
}

\author{
Melih GÜZEL ${ }^{* 1, a}$, Özlem AKPINAR ${ }^{2, b}$ \\ ${ }^{1}$ Gümüşhane Üniversitesi, Şiran Mustafa Beyaz Meslek Yüksekokulu, Otel Lokanta ve İkram Hizmetleri Bölümü, 29700, Gümüşhane \\ ${ }^{2}$ Gaziosmanpaşa Üniversitesi, Mühendislik ve Doğa Bilimleri Fakültesi, Glda Mühendisliği Bölümü, 60000, Tokat
}

• Geliş tarihi / Received: 20.03.2019 • Düzeltilerek geliş tarihi / Received in revised form: 29.07.2019 • Kabul tarihi / Accepted: 26.08 .2019

$\ddot{O} z$

Bitkiler, sağlık açısından olumlu etkileri olan fitokimyasallar bakımından zengindir. Bu çalışmada, Türkiye'de önemli miktarda tarımı yapılan kivi (Actinidia deliciosa), kavun (Cucumis melo), domates (Solanum lycopersicum), elma (Malus domestica), ayva (Cydonia oblonga) ve nar (Punica granatum) kabuklarının fitokimyasal bileşikleri belirlenmiştir. Çalışma kapsamında kabukların nem, kül, yağ, askorbik asit, $\beta$ karoten içerikleri belirlenmiş, kabuklar $\% 0, \% 25, \% 50$ ve $\% 75^{\prime}$ lik etanol çözeltilerinde ekstrakte edilmiş ve toplam fenolik, toplam flavonoid ve toplam monomerik antosiyanin içerikleri ve antioksidan kapasiteleri (FRAP, TEAC ve DPPH) incelenmiştir. Fenolik bileşikleri ekstrakte etmek için \%25 ve \%50 etanol konsantrasyonlarının, diğer konsantrasyonlara kıyasla daha başarılı olduğu sonucuna varılmıştır. Nar kabuğunun toplam monomerik antosiyanin, flavonoid, fenolik madde içerikleri ve antioksidan kapasiteleri açısından diğer kabuklara kıyasla oldukça yüksek olduğu saptanmıştır. İncelenen kabuklar arasında kavun kabuğunun diğer kabuklardan daha fazla miktarda $\beta$-karoten içerdiği, en yüksek askorbik asit içeriğine ise ayva kabuğunun sahip olduğu belirlenmiştir.

Anahtar kelimeler: Atık, Fenolik Bileşenler, Fitokimyasal, Kabuk, Meyve, Sebze

\begin{abstract}
Plants are rich in phytochemicals which have positive effects on health. In this study, the phytochemical components of the some fruit and vegatable peels, produced in the significant amounts in Turkey, including kiwi (Actinidia deliciosa), melon (Cucumis melo), tomato (Solanum lycopersicum), apple (Malus domestica), quince (Cydonia oblonga) and pomegranate (Punica granatum) were determined. The moisture, ash, fat, ascorbic acid and $\beta$ carotene contents of the peels were determined. Peels were extracted in 0\%, 25\%, 50\% and 75\% ethanol solutions and total phenolic, total flavonoids and total monomeric anthocyanin contents and antioxidant capacities of the extracts were investigated. It was concluded that the concentrations of $25 \%$ and $50 \%$ ethanol were more successful than other concentrations to extract the phenolic compounds. Total monomeric anthocyanin, flavonoid, phenolic contents and antioxidant capacity of the pomegranate peel were found to be significantly higher than the other peels. It was determined that the melon rind contained more $\beta$-carotene and quince peel contained more ascorbic acid content than the other peels.
\end{abstract}

Keywords: Antioxidant, Fruit, Phenolic, Phytochemicals, Vegetable, Waste

*aa Melih Güzel, melihguze1010@hotmail.com, Tel: (456)2331000-3608, https://orcid.org/0000-0001-5374-8838

bhttps://orcid.org/0000-0001-6593-8495 


\section{Giriş}

Bitkilerin kendine has rengi, kokusu ve tatlarının oluşumunda rol oynayan (Balch ve Balch, 1997), ikincil metabolit olarak ortaya çıkan ve besin maddesi olarak tüketildiklerinde sağlık açısından yararlı etkileri olan (Visioli vd., 2000), biyoaktif bileşiklere fitokimyasallar denilmektedir. Fitokimyasallar çoğunlukla kuvvetli antioksidan aktiviteye sahip olup (Schiassi vd., 2018), bağırsak florasını, safra asitlerini ve $\mathrm{pH}^{\prime} \mathrm{y} 1$ düzenlemekte, hücre içi matriks yapısının korunmasını sağlayarak hücreyi dış etkenlere karş1 korumaktadır. Bunun dışında antikarsinojenik enzim aktivitelerini arttırmakta, tümör ve kanser oluşumunda etkili olan maddelerin oluşumunu önleyici etkiye de sahiptir (Güney vd., 2003). Fitokimyasallar ve bu bileșenlerin beslenmedeki önemi, bilim ve teknoloji alanlarındaki gelişim, sağlık giderlerindeki yüksek maliyetler, insanların beslenme-sağlık ilişkisinde bilinçlenmesi, hayvansal gıdaların fazla tüketiminin sağlık üzerindeki olumsuz etkilerinden dolayı giderek artmaktadır (Kırışoğlu ve Velioğlu, 2001). En bilinen fitokimyasal bileşikler; tanenler, fenolik bileşikler (polifenoller), karotenoidler, saponinler, kumarinler, tokoferoller, terpenler, izotiyosiyanatlar, sülfitler, sülforafanlar, terpenoidler, alkaloidler, flavonoidler, fitosteroller, fitoestrojenler, indoller şeklinde siralanabilir (Dündar, 2001).

Fitokimyasalların en büyük grubunu fenolik bileşikler oluşturmaktadır (Haslam, 1998). Fenolikler, antioksidan özelliklerinin yanında; antialerjen, antimutajen, antikanserojen, antiglisemik, antikolesterol, anti-inflamatuar, antimikrobiyal ve sakinleştirici özelliklere de sahip olup, kozmetik, ilaç ve gıda endüstrisinde ise katk1 maddesi olarak kullanılmaktadır (Friedman ve Levin, 2009). Son yıllarda gida işleme sonucunda oluşan atık kütleler, fenolik bileşiklerin ucuz ve güvenli kaynakları olarak ilgi çekmektedir (Cam ve Aaby, 2010). Fenolik maddeler yapılarına göre flavonoidler (antosiyanidinler, flavonlar, flavonollar, flavanonlar, proantosiyanidinler, kateşinler ve löykoantosiyanidinler), fenolik asitler, lignanlar ve stilbenler olarak ayrılmaktadır (Fernandez vd., 2008). Flavonoid bileşiklerinin antioksidan (Larson, 1988), antimikrobiyal (Pratt ve Hudson, 1990), antiviral, antiülser, hipolidemik, hepatoprotektif (Wagner vd., 1991), antienflamatuar (Moroney vd., 1988), antimutajen ve antikanserojen (Deschner vd., 1991) gibi aktivite gösterdikleri anlaşılmıştır.
Antosiyanidinlerin şekerler ile glikozit yaparak oluşturduğu antosiyanin flavonidi, meyve ve sebzelerde pembeden, kırmızı ve mor tonları gibi çeşitli renklerden sorumlu, suda çözünebilen pigmentler olduğundan (Nizamlığlu ve Nas, 2010), gidaların renklendirilmesinde doğal boya olarak sentetik boyalara karşı alternatif olarak da kabul edilmektedir. Bugüne kadar 4000'den fazla izole edilmiş flavonoid bileşiklerin (gıda, tekstil, deri, metalürji, tıp, ziraat gibi alanlarda kullanılabilme potansiyelinden dolayı son yıllarda bunlarla ilgili çalışma sayısı giderek artmaktadır (İnanir vd., 2019).

Doğada yaygın olarak bulunan doğal renk pigmentleri olan karotenoidlerin yaklaşı \% $\% 90$ ' $\mathrm{n}$ 1 $\alpha^{-}$ve $\beta$-karoten oluşturmakta ve özellikle provitamin A aktivitesinden dolayı önemli bir fitokimyasal grubunu temsil etmektedir (Larson, 1997). Bitkilerde yaygın olarak bulunan önemli bir diğer fitokimyasal ise askorbik asit olup, vitamin aktivitesinin yanında kalp-damar hastalıkları, sinirsel hastalıklar ve bazı kanser türlerine karşı risk azaltıcı ve radikallerin oluşturduğu DNA hasarlarını önleyici etkileri vardır. Sahip oldukları antioksidan özellikleri sayesinde, lipid oksidasyonunu serbest radikal ve oksijen bağlayıcı olarak indirgen özellik göstererek, daha az reaktif olan türlerine dönüştürmekte, radikalleri etkisiz hale getirmekte ve bazı antioksidanları yenilemektedir (Koca ve Karadeniz, 2005). Bazı meyvelerde örneğin portakalda, meyve kabuğunun, meyve suyundan çok daha fazla miktarda askorbik asit içerdiği belirtilmektedir (URL-1, 2014).

Dünya meyve ve sebze üretiminde lider ülkeler arasında bulunan Türkiye, Birleşmiş Milletler Gıda ve Tarım Örgütü 2017 verilerine göre ayva üretiminde dünyada birinci, kavun üretiminde ikinci, elma ve domates üretiminde üçüncü, kivi ve nar üretiminde ise sekizinci surada bulunmaktadır (FAO, 2017). Türkiye İstatistik Kurumu verilerine göre 2018 yılında Türkiye' de üretilen kivi, kavun, domates, elma ayva ve nar üretim miktarları sırasıyla 61,920 ton, $1,753,942$ ton, $12,150,000$ ton, $3,625,960$ ton, 176,479 ton ve 537,847 tondur (TÜIK, 2018). Dolayisiyla bu ürünlerin tüketilmesi veya işlenmesi sırasında önemli miktarda hem evsel hem de endüstriyel boyutta atık ortaya çıkmaktadır.

Atıkların değerlendirilmesi amacıyla dünya genelinde yoğun çalışmalar yapılmaktadır (Wolfe vd., 2003; Lim vd., 2006; Ghasemi vd., 2009). Gıda endüstrisi atıklarının sadece bir kısmı kompost edilerek ya da kurutularak yem veya 
gübre olarak kullanılmakta olup, bu atıklardan ekonomik değeri daha yüksek olan fitokimyasal maddeler elde edilmesi için sürdürülebilir kaynak olarak kullanılması, atık yönetimi açısından daha doğru bir yaklaşımdır (Poli vd., 2011). Yapılan çalışmalarda, meyve-sebze kabuklarının önemli düzeyde fitokimyasalları içerdiği belirlenmiştir (Fidrianny vd., 2014; Canan vd., 2016). Pek çok çalışmada meyve-sebze kabuk ve çekirdeklerinin fitokimyasal içeriğinin, yenilebilir dokuya kıyasla daha fazla olduğu (Shrikhande, 2000; Gorinstein vd., 2004; Someya vd., 2002; George vd., 2004) ve bu maddelerin kozmetik, ilaç ve gıda sanayinde yüksek değerli ürünlerin elde edilmesinde kullanılabileceği (Ashoush ve Gadallah, 2011) belirtilmiştir.

\section{Amaç}

Bu çalışmanın amacı, Türkiye'de önemli düzeyde tarımı yapılan kivi, kavun, domates, elma, ayva ve nar meyve-sebzelerin kabuklarında bulunan fitokimyasal bileşikleri ve antioksidan özelliklerini belirlemek ve elde edilen sonuçları karşılaştırarak, meyve-sebzelerin birbirlerine karş1 üstünlüklerini araştırmaktır. $\mathrm{Bu}$ amaç doğrultusunda kivi, kavun, domates, elma, ayva ve nar kabuklarının kül, $\beta$-karoten, askorbik asit içerikleri belirlenmiş, içerdikleri fenolik bileşiklerin yüksek oranda ekstraksiyonu için uygun etanol konsantrasyonu araştırılmış ve antoksidan aktiviteleri belirlenmiştir. Ayrıca yine sağllk açısından öneme sahip tanen, kinon, kardiyak glikozit, terpenoid, kumarin gibi fitokimyasal bileşiklerin varlığı da kalitatif olarak araştırılmıştır.

\section{Gereç ve Yöntem}

\subsection{Materyal}

Çalışma kapsamında kabukların elde edilmesi için gerekli meyve-sebzeler; kivi (Actinidia deliciosa), kavun (Cucumis melo), domates (Solanum lycopersicum), elma (Malus domestica), ayva (Cydonia oblonga) ve nar (Punica granatum), kültivar fark1 gözetmeksizin yerel marketlerden temin edilmiştir. Taze meyve-sebzelerin kabukları, kabuk soyucu (Tefal Talent K07906 Peeler) ile 2-3 mm kalınlığında ayrılmış, doğrayıc1 ile parçalanmış, $50^{\circ} \mathrm{C}$ 'de etüvde kurutulmuş, öğütülmüş ve $4^{\circ} \mathrm{C}^{\prime} \mathrm{de}$ cam kavanozlarda depolanmıştır. Kullanılan tüm standart ve kimyasallar (ABTS, TPTZ, DPPH, Trolox, Quercetin, $\beta$-karoten, askorbik asit ve butilhidroksitoluen (BHT), 3,4,5trihidroksibenzoik asit (gallik asit), Folin-
Ciocalteu reaktifi, demir (III) klorit hekzahidrat, potasyum persülfat, furfural ve diğer kimyasallar) Sigma (MO, ABD) ve Merck (Darmstadt, Almanya)'den tedarik edilmiştir.

\subsection{Yöntem}

\subsubsection{Kurumadde, Kül ve Yă̆}

Örneklerin yağ miktarı yağ ekstraksiyon cihazında (Ankom XT10), kurumadde ve kül oranları ise gravimetrik olarak belirlenmiştir (AOAC, 1989).

\subsection{2. 及-karoten ve Askorbik Asit}

Öğütülmüş meyve-sebze kabuklarından $\beta$-karoten ekstraksiyonu için, $0.6 \mathrm{~g}$ kabuk, $6 \mathrm{~mL} \% 0.1$ etanolik BHT (bütil hidroksi tolüen) ile karıştırılmış ve önce $85^{\circ} \mathrm{C}$ ' deki su banyosunda 5 dakika bekletilmiş, daha sonra \%80 KOH $(0.5$ $\mathrm{mL}$ ) ilave edilmiştir. Örnekler tekrar karıştırılarak $85^{\circ} \mathrm{C}$ 'de su banyosunda bekletilmiş (10 dakika) ve 5 dakika karıştırıldıktan sonra, buz içerisine soğutulmuş ve üzerine $3 \mathrm{~mL}$ soğuk deiyonize su ilave edilmiştir. Soğutulmuş örneğe, $3 \mathrm{~mL}$ hekzan ilave edilmiş, üstteki karotenoitçe zengin tabaka ayrılmış ve bu kısmın absorbansı $450 \mathrm{~nm}$ 'de hekzana karşı okunmuştur. Örneklerin $\beta$-karoten miktar1, $\beta$-karoten (Sigma-Aldrich (St. Louis, $\mathrm{ABD})$ ) standardı kullanarak hesaplanmıştır (Sanusi ve Adebiyi, 2009).

Kabukların toplam askorbik asit içerikleri spektrofotometrik yöntemle belirlenmiştir (Hış1l, 2004). 10 g kabuk, $90 \mathrm{~g}$ stabilizan çözeltisi (\%0.4'lük okzalik asit) ile karıştırılarak filtre edilmiş, $1 \mathrm{~mL}$ filtrat $9 \mathrm{~mL}$ boya çözeltisi ile (2.6dichloroindophenol, Na tuzu) karışıtılmış ve 518 nm'de absorbansı ölçülmüştür. Örneklerin askorbik asit içerikleri farklı konsantrasyonlarda L-askorbik asit (Sigma-Aldrich (St. Louis, ABD)) standardı kullanarak hesaplamıştır.

\subsection{3. Örneklerin Ekstraksiyonunun Hazırlanması}

Meyve-sebze kabuklarının fenolik bileşikleri farkl k kosantrasyonlarda etanol ile ekstraksiyonuna tabi tutulmuştur. $0.5 \mathrm{~g}$ ögütülmüş meyve-sebze kabuklarina $20 \mathrm{~mL} \% 0, \% 25, \% 50$ ve $\% 75^{\prime}$ lik etil alkol ilave edilerek çalkalamalı su banyosunda $60^{\circ} \mathrm{C}$ 'de 30 dakika boyunca ekstraktraksiyona tabii tutulmuş ve ekstraksiyon sonunda filtre edilmiştir. Elde edilen esktraktlar bir sonraki analizler için kullanılana kadar $18^{\circ} \mathrm{C}^{\prime}$ de depolanmıştır. 


\subsubsection{Suda Çözünür Kuru Madde}

Ekstraktların suda çözünür kuru maddesi Abbe refraktometresi (Centro de Enseñanza Técnica Industrial (Ceti), Meksika) ile tayin edilmiştir. Ölçümler oda sıcaklığında $\left(25^{\circ} \mathrm{C}\right)$ yapılmış ve sonuçlar \% ( ${ }^{\circ}$ Briks) olarak ifade edilmiştir (Cemeroğlu, 2010).

\subsubsection{Kalitatif Analizler}

Meyve-sebze kabuk ekstraktlarının içerdiği diğer fitokimyasal bileşikler hakkında fikir edinilmesi için tanen, saponin, kinon, kardiak glikozit, terpenoid ve kumarin içerikleri kalitatif olarak incelenmiştir. Tanen analizi için ekstraktlardan $0.25 \mathrm{~mL}$ alınıp üzerine $0.5 \mathrm{~mL} \% 52^{\prime}$ lik $\mathrm{FeCI}_{3}$ eklenmiş, yeşil renk oluşumu gözlenenlerde tanen varlığı pozitif olarak değerlendirilmiştir. Saponin analizi için ekstraktlarından $0.5 \mathrm{~mL}$ alınıp üzerine $0.5 \mathrm{~mL}$ distile su eklenerek çalkalanmış, 15 dakika beklenmiş, yaklaşı $0.25 \mathrm{~cm}$ köpük oluşumu gözlenenlerde saponin bulunduğu belirtilmiştir. Kinon analizi için ekstraktlardan $0.25 \mathrm{~mL}$ alınıp üzerine $0.25 \mathrm{~mL} \mathrm{H}_{2} \mathrm{SO}_{4}$ eklenmiş, kırmızı renk oluşumu gözlenenlerde kinon varlığ gözlenmiştir. Kardiak glikozit analizinde $0.25 \mathrm{~mL}$ ekstrakta $1 \mathrm{~mL}$ asetik asit, birkaç damla \%5'lik $\mathrm{FeCI}_{3}$ ve $0.5 \mathrm{~mL} \mathrm{H} \mathrm{SO}_{4}$ eklenmiş, kahverengi renk oluşumu gözlenenlerde, kardiak glikozit varlığ 1 belirlenmiştir. Terpenoid analizinde 0.25 $\mathrm{mL}$ ekstrakta $1 \mathrm{~mL}$ kloroform ve birkaç damla $\mathrm{H}_{2} \mathrm{SO}_{4}$ eklenmiş, kırmızı renk oluşumu gözlenenlerde terpenoid, kumarin analizi için ise ekstraktlardan $0.25 \mathrm{~mL}$ alınıp üzerine $0.25 \mathrm{~mL}$ \%10'luk $\mathrm{NaOH}$ eklenmiş, sarı renk oluşumu gözlenenlerde kumarin varlıkları pozitif olarak değerlendirilmiştir (Janarthanan vd., 2012).

\subsubsection{Toplam Fenolik Madde}

Meyve-sebze ekstraktlarının toplam fenolik madde miktarları Singleton vd. (1965)'nın tanımladığı yöntemin modifikasyonu ile belirlenmiştir. $\mathrm{Bu}$ amaçla $100 \mu \mathrm{L}$ Folin-Ciocalteu
( $2 \mathrm{~N}), 100 \mu \mathrm{L}$ meyve-sebze kabuk ekstraktı ile 2.3 $\mathrm{mL}$ distile su ve $1 \mathrm{~mL}$ sodyum karbonat çözeltisi (\%7) ile karıştırılmış ve 2 saat oda sıcaklığında bekletilmiştir. Çözeltilerin absorbansları ise 750 nm'de ölçülmüş ve sonuçlar gallik asit eşdeğeri (GAE) olarak hesaplanmıştır.

\subsubsection{Toplam Flavonoid}

Ekstraktların toplam flavonoid miktarları, Li vd. (2015) tarafindan belirtilen yönteme göre belirlenmiştir. $0.5 \mathrm{~mL}$ meyve-sebze ekstraktlarına $2 \mathrm{~mL}$ distile su ve $0.15 \mathrm{~mL} \mathrm{NaNO}_{2}(\% 5)$ ilave edilerek karıştırılmış, 5'er dakika ara ile önce 0.15 $\mathrm{mL} \mathrm{AlCI}_{3}(\% 10)$, sonra $1 \mathrm{~mL} \mathrm{NaOH}(1 \mathrm{M})$ ilave edilmiş ve 15 dakika boyunca reaksiyona girmesi için beklenmiş ve 415 nm'de absorbansları ölçülmüştür. Standart olarak etanolde hazırlanmış $200 \mathrm{mg} / \mathrm{L}$ stok kuarsetin (Sigma-Aldrich (St. Louis, ABD)) çözeltisi kullanılmış ve sonuçlar kuarsetin eşdeğeri (KE) olarak ifade edilmiştir.

\subsubsection{Toplam Monomerik Antosiyanin}

Ekstraktların toplam monomerik antosiyan miktarının belirlenmesi için Fuleki ve Francis (1968) tarafindan belirtilen $\mathrm{pH}$ diferansiyel yöntemi uygulanmıştır. Bunun için $10 \mathrm{~mL}$ meyvesebze ekstraktlarının pH'ları, $\mathrm{HCl}(0.1 \mathrm{~N})$ ve $\mathrm{NaOH}(0.1 \mathrm{~N})$ çözeltileri ile 1.00 ve 4.50 'ye ayarlanmıştır. pH'ları ayarlanmış ekstraktların hacimleri $50 \mathrm{~mL}$ 'ye distile su ile tamamlanarak $4^{\circ} \mathrm{C}$ 'de 2 saat bekletildikten sonra örneklerin absorbansları $516 \mathrm{~nm}$ ve 700 nm'de ölçülmüsstür. Ekstraktlarının toplam antosiyanin içerikleri denklem (1) ve (2)'ye göre hesaplanmıştır.

$\mathrm{Bu}$ bağıntıda A absorbans değerini, A516 ve A700 sirasiyla 516 ve $700 \mathrm{~nm}$ 'de absorbans derğerlerini, DF seyreltme faktörünü, $\varepsilon$ siyanidin-3-glikozitin molar absorbsivitesini (29.600), L küvet optik yolunu $(1 \mathrm{~cm})$ ve MW ise siyanidin-3-glikozitin molekül ağırlı̆̆ını (445.2) ifade etmektedir.

$A=(A 516-A 700) p H 1.0-(A 516-A 700) p H 4.5$

Toplam Antosiyanin $(\mathrm{mg} / \mathrm{l})=[(A) \times(103) \times(M W) \times(D F)] /[(\varepsilon) \times(L)]$

\subsubsection{Antioksidan Aktivite}

Meyve-sebze kabuk ekstraktlarının antioksidan tayinleri, Demir (III) İndirgeme Antioksidan Gücü (FRAP) (Benzie ve Strain, 1996), Troloks Eşdeğeri Antioksidan Kapasitesi (TEAC) (Re vd.,
1999) ve Radikal Süpürme Aktivitesi (DPPH) (Brand-Williams vd., 1995) yöntemlerine göre gerçekleştirilmiştir. FRAP yönteminde $30 \mathrm{mM}$ sodyum asetat tampon çözeltisi $(\mathrm{pH}$ 3.6), sulu demir (III) klorür çözeltisi $(20 \mathrm{mM})$ ve sulu 2,4,6tripiridil-S-triazin (TPTZ) çözeltisi $(10 \mathrm{mM})$ 
10/1/1 oranında karıştırılarak FRAP çalışma çözeltisi hazırlandı. Bu çözelti $(2.9 \mathrm{~mL})$ ve meyve-sebze ekstraktları $(100 \mu \mathrm{l})$ veya troloks standart çözeltileri $(100 \mu$ l) karıştırılarak, oda sıcaklığında 30 dakika bekletildikten sonra absorbansları (593 nm) belirlenmiştir. TEAC yönteminde sulu 2,2'- azino- bis (3etilbenzotiyazolin-6-sülfonik asit) (ABTS) çözeltisi $(7 \mathrm{mM})$ ve sulu potasyum persülfat çözeltisi $(2.45 \mathrm{mM})$ karışımı $(1 / 1, \mathrm{v} / \mathrm{v})$ oda sıcaklığında karanlık bir ortamda reaksiyona birakilarak (16 saat) ABTS radikal katyonu (ABTS'+) stok çözeltisi elde edilmiştir. Bu çözelti sodyum asetat ( $\mathrm{pH} 4.5,20 \mathrm{mM})$ ile seyreltilerek $734 \mathrm{~nm}$ dalga boyunda absorbans1 0.7'ye ayarlanarak elde edilen ABTS'+ çalışma çözeltisi $(2.9 \mathrm{~mL})$ ve ekstraktlar $(0.1 \mathrm{~mL})$ veya troloks standart çözeltileri karıştırıldıktan sonra, oda sıcaklığında 30 dakika bekletilerek, $734 \mathrm{~nm}$ dalga boyunda absorbans değerleri ölçülmüştür. DPPH yönteminde 2,2 difenil-1- pikrilhidrazil (DPPH) çalışma çözeltisi $(1.95 \mathrm{~mL})$ ve ekstraktlar $(50 \mu \mathrm{l})$ veya troloks standart çözeltileri $(50 \mu \mathrm{l})$ karıştırılarak oda sıcaklığında $10 \mathrm{dk}$ inkübe edildikten sonra 517 nm'de absorbanslar1 ölçülerek hesaplanmıştır. Ekstraktların antioksidan kapasite değerlerleri troloks eşdeğeri (TE) olarak hesaplanmıştır.

\section{3. İstatistiksel Analiz}

Sonuçlar üç tekrar ortalaması \pm standart sapma olarak verilmiştir. İstatistiksel bilgisayar programı sonuçlarınının analizi için SPSS kullanılmış (IBM SPSS Statistics 22, Inc., Chicago, IL, USA), sonuçların varyans analizleri yapılmış (ANOVA) ve sonuçlar arasındaki farklilıklar ise Duncan çoklu karşılaştırma testi ile istatistiksel olarak \%95 güven aralığında değerlendirilmiştir.

\section{Bulgular ve Tartışma}

Nem miktarı gıdalardaki su içeriğinin, kül miktarı ise mineral madde ve diğer inorganik madde içeriğinin bir göstergesidir (Acquistucci vd., 1991). Bu çalışmada kurutulmuş meyve-sebze kabuklarında önce nem, ardından da kül tayini yapılmıştır. Kurutma işlemi tüm kabuklar için aynı koşullarda olmasına rağmen, domates kabuklarının nem içeriğinin, diğer kabuklara kıyasla daha fazla olduğu belirlenmiştir (Tablo 1). Domates, kavun ve kivi kabuklarının kül oranlarının diğer kabuklara kıyasla yüksek olduğu saptanmıştır (Tablo 1). Daha önceki çalışmalarda kavun kabuğunun (\%9.7) (Morais vd., 2017) ve nar kabuğunun (\%6.07) (Romelle vd., 2016) kül içeriklerinin çalışmamızda elde edilen sonuçlardan daha yüksek olduğu, elma kabuğunun (\%1.39) (Romelle vd., 2016) ise daha düşük olduğu belirlenmiştir.

İncelenen meyve-sebze kabuklarının yă içeriklerinin \%1.62-3.61 arasında değiştiği gözlenmiştir (Tablo 1). En yüksek yağ içeriğine sahip kabuk, ayva olup bunu elma takip etmektedir. Daha önceki çalışmalarda nar ve elma kabuklarının (\%3.36, \%9.96) (Romelle vd., 2016) çalışmamızda bulunan değerlerden daha yüksek olduğu saptanmıştır. Literatür çalışmalarında bildirilen kül ve yağ içerikleri ile çalışmamızdaki meyve-sebze kabuklarının içerikleri arasındaki farkların, iklim koşulları, toprak bileşimi gibi meyve-sebze yetiştirilme şartlarından, tür ve cins farklılıklarından, hasat sürelerinden ve kabuk soyma yöntemleri gibi çeşitli koşuldan kaynaklanabileceği düşünülmektedir.

İncelenen meyve-sebze kabuklarının, provitamin A özelliği gösteren karotenoidlerin önemli bir grubunu temsil eden $\beta$-karoten (Garcia ve Baret, 2005) içerikleri karşılaştırıldığında, kabuklarının 2.15-93.29 ppm arasında $\beta$-karoten içerdiği, kavun kabuğunda ise en fazla olduğu, bunu sirasiyla, domates ve kivi kabuğunun izlediği, en düşük içeriğe ise sirasıyla elma, ayva ve nar kabuğunun sahip olduğu bulunmuştur (Tablo 1). Daha önceki çalışmalarda, crenshaw kavununun $450 \mu \mathrm{g} / 100 \mathrm{~g}$, kantalup kavununun $1595 \mu \mathrm{g} / 100 \mathrm{~g}$, domatesin $393 \mu \mathrm{g} / 100 \mathrm{~g}$ (Holden vd., 1999), elmanın 72 $\mu \mathrm{g} / 100 \mathrm{~g}$ (Setiawan vd., 2001), taze salatalı̆̆ın 280 ve domatesin $1610 \mu \mathrm{g} / 100 \mathrm{~g}$ (Ahamad vd. 2007) $\beta$-karoten içerdiği bildirilmiştir. Sonuçlar karşılaştırıldığında Ahamad vd. (2007) tarafindan domates için belirtilen $\beta$-karoten içeriği hariç diğer sonuçlarda belirtilen değerlerin çalışmamıza göre daha düşük olduğu sonucu görülmektedir.

Tablo 1 incelendiğinde en yüksek askorbik asit içeriğine $100.00 \mathrm{mg} / 100 \mathrm{~g}$ kabuk ile ayva kabuğunun sahip olduğu, bunu sirasiyla nar, domates ve elma kabuğunun takip ettiği, kavun, domates ve elma kabuklarının askorbik asit içerikleri arasında istatistiki olarak fark bulunmadığ1, en düşük içeriğe ise $22.90 \mathrm{mg} / 100 \mathrm{~g}$ ile kivi kabuğunun sahip olduğu görülmektedir. Daha önceki çalışmalarda, domates kabuğunun 16.9 (Toor ve Savage, 2005), ayva kabuğunun 18.74 (Silva vd., 2004), salatalığın 1.49, kavunun 2.32 ve domatesin 12.16 (Melo vd., 2006), elmanın 12.72, salatalığın 12.00, kavunun 26.42 ve domatesin $27.70 \mathrm{mg} / 100 \mathrm{~g}$ (Okiei vd., 2009) askorbik asit içerdiği belirtilmiştir. Sonuçlar karşılaştırıldığında çalışmamızda elde edilen değerin daha yüksek olduğu gözükmektedir. 
Tablo 1. Meyve-sebze kabuklarının bazı bileşenleri

\begin{tabular}{cccccc}
\hline & Nem $(\%)$ & Kül $(\%)$ & Yağ $(\%)$ & $\begin{array}{c}\text { B-karoten } \\
(\boldsymbol{\mu g} / \mathbf{g})\end{array}$ & $\begin{array}{c}\text { Askorbik Asit } \\
(\mathbf{m g} / \mathbf{1 0 0 g})\end{array}$ \\
\hline Kivi & $8.45 \pm 0.16^{\mathrm{b}}$ & $6.96 \pm 0.00^{\mathrm{c}}$ & $2.21 \pm 0.01^{\mathrm{c}}$ & $5.19 \pm 0.18^{\mathrm{c}}$ & $22.90 \pm 1.60^{\mathrm{d}}$ \\
Kavun & $7.40 \pm 0.20^{\mathrm{d}}$ & $8.69 \pm 0.09^{\mathrm{b}}$ & $1.84 \pm 0.02^{\mathrm{e}}$ & $43.54 \pm 0.18^{\mathrm{a}}$ & $51.25 \pm 3.21^{\mathrm{c}}$ \\
Domates & $10.26 \pm 0.31^{\mathrm{a}}$ & $10.56 \pm 0.02^{\mathrm{a}}$ & $2.19 \pm 0.02^{\mathrm{c}}$ & $13.20 \pm 0.184^{\mathrm{b}}$ & $52.39 \pm 1.60^{\mathrm{c}}$ \\
Elma & $3.64 \pm 0.11^{\mathrm{f}}$ & $2.14 \pm 0.01^{\mathrm{f}}$ & $3.49 \pm 0.0^{\mathrm{b}}$ & $2.15 \pm 0.09^{\mathrm{f}}$ & $52.38 \pm 1.60^{\mathrm{c}}$ \\
Ayva & $5.07 \pm 0.05^{\mathrm{e}}$ & $2.28 \pm 0.01^{\mathrm{e}}$ & $3.61 \pm 0.01^{\mathrm{a}}$ & $2.62 \pm 0.13^{\mathrm{e}}$ & $100.00 \pm 1.60^{\mathrm{a}}$ \\
Nar & $7.92 \pm 0.23^{\mathrm{c}}$ & $4.24 \pm 0.01^{\mathrm{d}}$ & $1.92 \pm 0.02^{\mathrm{d}}$ & $2.99 \pm 0.13^{\mathrm{d}}$ & $72.79 \pm 1.60^{\mathrm{b}}$ \\
\hline
\end{tabular}

Duncan testine göre aynı sütundaki farklı harflerle $\left({ }^{\mathrm{a}, \mathrm{b}, \mathrm{c}, \mathrm{d}, \mathrm{e}, \mathrm{f}}\right)$ belirtilmiş ortalamalar birbirinden farklı olup (p<0.05), değerler 3 paralelin ortalaması ve standart sapma olarak ifade edilmiştir.

Bitkisel materyallerden fenolik bileşiklerin ekstraksiyon verimini artırmak amaciyla farklı polaritelere sahip solventler kullanılmaktadır (Paula vd., 2014; Waszkowiak ve Swiglo, 2016). Meyve-sebze kabukları, farklı konsantrasyonlarda düşük toksisiteye sahip etil alkol ile ekstrakte edilmiş ve ekstraktların suda çözünür kurumadde (SÇKM) miktarları Tablo 2'de verilmiştir. Artan etanol konsantrasyonunun ekstraktların SÇKM içeriklerini önemli ölçüde $(\mathrm{P}<0.05)$ arttırdığ gözlenmiştir. Örneğin $\quad \% 0$ etanol $\quad(\mathrm{su})$ konsantrasyonunda ekstraktların suda çözünür kuru madde içeriği \%0.97-1.37 arasında iken \%75 etanol konsantrasyonunda ise \%20.10-21.00 aralığında olduğu belirlenmiştir. Buna karşın aynı etanol konsantrasyonlarında ekstrakte edilen ekstraktlar arasında fark olmadiğı $\quad(\mathrm{P}<0.05)$ gözlenmiştir. Ekstraktlar arasında en yüksek SÇKM içeriğine \%75 etanol konsantrasyonunda elde edilen elma ekstrakt1, aynı konsantrasyonda en düşük içeriğe ise domates kabuk ekstraktı sahiptir.

Tablo 2. Ekstraktların suda çözünür kuru madde miktarları (\%)

\begin{tabular}{lcccc}
\hline & $\mathbf{\% 0}$ & $\mathbf{\% 2 5}$ & $\mathbf{\% 5 0}$ & $\mathbf{\% 7 5}$ \\
\hline Kivi & $1.00 \pm 0.00^{\mathrm{CD}}$ & $10.02 \pm 0.03^{\mathrm{dC}}$ & $17.02 \pm 0.03^{\mathrm{cB}}$ & $20.42 \pm 0.03^{\mathrm{bA}}$ \\
Kavun & $1.37 \pm 0.03^{\mathrm{aD}}$ & $10.02 \pm 0.03^{\mathrm{dC}}$ & $17.02 \pm 0.03^{\mathrm{CB}}$ & $20.30 \pm 0.00^{\mathrm{cA}}$ \\
Domates & $1.00 \pm 0.00^{\mathrm{cD}}$ & $10.02 \pm 0.03^{\mathrm{dC}}$ & $16.92 \pm 0.03^{\mathrm{dB}}$ & $20.10 \pm 0.00^{\mathrm{eA}}$ \\
Elma & $0.97 \pm 0.03^{\mathrm{CD}}$ & $10.42 \pm 0.03^{\mathrm{aC}}$ & $17.82 \pm 0.03^{\mathrm{aB}}$ & $21.00 \pm 0.00^{\mathrm{aA}}$ \\
Ayva & $1.20 \pm 0.00^{\mathrm{bD}}$ & $10.32 \pm 0.03^{\mathrm{bC}}$ & $17.42 \pm 0.03^{\mathrm{bB}}$ & $20.25 \pm 0.03^{\mathrm{dA}}$ \\
Nar & $1.20 \pm 0.00^{\mathrm{bD}}$ & $10.07 \pm 0.03^{\mathrm{cC}}$ & $17.02 \pm 0.03^{\mathrm{CB}}$ & $20.42 \pm 0.03^{\mathrm{bA}}$ \\
\hline
\end{tabular}

Duncan testine göre aynı sütunda farklı harflerle $\left(^{\mathrm{a}, \mathrm{b}, \mathrm{c}, \mathrm{d}, \mathrm{e}, \mathrm{f}}\right)$ ve aynı satırda farklı harflerle $\left({ }^{\mathrm{A}, \mathrm{B}, \mathrm{C}, \mathrm{D}}\right.$ ) belirtilmiş ortalamalar birbirinden farklı $(\mathrm{p}<0.05)$ olup, değerler 3 paralelin ortalaması ve standart sapma olarak ifade edilmiştir.

Meyve-sebze kabuk ektraktlarının toplam fenolik madde içerikleri Tablo 3'te sunulmuştur. Kabuk ekstraktları arasında, en yüksek fenolik madde içeriğine narın sahip olduğu belirlenmiş olup, bunu elma ve ayvanın takip ettiği, en düşük değere ise domates kabuğunun sahip olduğu saptanmıştır. Optimum fenolik madde ekstraksiyonunun gerçekleștiği etanol konsantrasyonunun, farkl1 meyve ve sebze kabukları için değiştiği örneğin kivi, kavun ve nar kabukları için bu oran \%25 iken, domates, elma ve ayva kabukları için ise $\% 50$ etanol konsantrasyonu olduğu belirlenmiştir. Daha önce literatürde yapılan çalışmalar incelendiğinde, Henríquez vd. (2010) tarafindan elma kabuklarının pulp ve tüm meyveye kıyasla meyve türüne bağlı olarak sırasıyla 4.6-8.1 ve 3.5-4.9 kat daha fazla fenolik madde içerdiği ve kabuğun fenolik madde içeriğinin elma türüne bağlı olarak yaklaşık 6-12 mg GAE/g olduğu bildirilmiştir. Diğer çalışmalarda elma (kırmızı), elma (yeşil), domates, kivi ve kavun kabuklarının sırasiyla $3.89,4.37,3.07,4.26$ ve $5.10 \mathrm{mg}$ GAE/g (Deng vd., 2012), elma ve kivi kabuklarının sırasıyla 11.48 ve $5.89 \mathrm{mg}$ GAE/g (Afsharnezhad vd. (2017), ayva kabuğunun 7.09 mg GAE/g fenolik madde içerdiği ve ayva kabuğunun pulp ve çekirdeğe kıyasla sırasıyla 4.7 ve 25.9 kat daha fazla fenolik madde içerdiği (Silva vd., 2004) belirtilmiştir. Sonuçlar karşılaş̧ırıldığında, bu çalışmadaki sonuçların, literatür sonuçlarından daha yüksek olduğu ve özellikle $\% 25$ ve $\% 50$ etil alkol konsantrasyonun fenolik bileşiklerin ekstraksiyonunda oldukça etkili olduğu sonucuna varılmıştır. 
Tablo 3. Ekstraktların toplam fenolik madde miktarları (mg GAE/g)

\begin{tabular}{lcccc}
\hline & \%0 & \%25 & \%50 & \%75 \\
\hline Kivi & $38.27 \pm 1.04^{\mathrm{bD}}$ & $79.01 \pm 2.98^{\mathrm{cA}}$ & $72.17 \pm 1.04^{\mathrm{dB}}$ & $60.69 \pm 0.00^{\mathrm{cC}}$ \\
Kavun & $43.54 \pm 0.45^{\mathrm{bAB}}$ & $52.48 \pm 0.89^{\mathrm{cdA}}$ & $48.48 \pm 3.28^{\mathrm{eAB}}$ & $41.33 \pm 5.36^{\mathrm{dB}}$ \\
Domates & $39.33 \pm 0.15^{\mathrm{bB}}$ & $39.96 \pm 1.34^{\mathrm{dB}}$ & $49.22 \pm 0.74^{\mathrm{eA}}$ & $34.91 \pm 0.74^{\mathrm{dC}}$ \\
Elma & $80.59 \pm 3.13^{\mathrm{bD}}$ & $121.85 \pm 1.64^{\mathrm{bB}}$ & $138.38 \pm 2.98^{\mathrm{bA}}$ & $110.17 \pm 0.89^{\mathrm{bC}}$ \\
Ayva & $74.48 \pm 1.04^{\mathrm{bC}}$ & $120.17 \pm 1.64^{\mathrm{bB}}$ & $128.69 \pm 1.79^{\mathrm{cA}}$ & $118.17 \pm 2.98^{\mathrm{bB}}$ \\
Nar & $1374.32 \pm 46.15^{\mathrm{aC}}$ & $1630.11 \pm 29.77^{\mathrm{aA}}$ & $1551.16 \pm 4.47^{\mathrm{aB}}$ & $1539.58 \pm 8.93^{\mathrm{aB}}$ \\
\hline
\end{tabular}

Duncan testine göre aynı sütunda farklı harflerle $\left({ }^{\mathrm{a}, \mathrm{b}, \mathrm{c}, \mathrm{d}, \mathrm{e}, \mathrm{f}}\right)$ ve aynı satırda farklı harflerle $\left({ }^{\mathrm{A}, \mathrm{B}, \mathrm{C}, \mathrm{D}}\right)$ belirtilmiş ortalamalar birbirinden farklı $(\mathrm{p}<0.05)$ olup, değerler 3 paralelin ortalaması ve standart sapma olarak ifade edilmiştir.

Kavun ve domates kabuk ekstraktlarının flavonoid içeriği artan etanol konsantrasyonu ile artmış, elma, ayva ve nar kabuğu ekstraklairnda en yüksek flavonoid içeriğine $\% 50$ etanol konsantrasyonunda kivi kabuğu ekstraktında ise $\% 25$ etanol konsantrasyonunda ulaşılmıştır. İncelenen kabuklar arasında en yüksek flavonoid içeriğine, fenolik madde içeriğine benzer olarak nar kabuğunun sahip olduğu, bunu ayva ve elma kabuklarının takip ettiği, en düşük flavonoid içeriğine ise fenolik madde içeriğine benzer olarak domates kabuğunun sahip olduğu gözlenmiştir
(Tablo 4). Literatür çalışmaları incelendiğinde, nar kabuğunun flavonoid içeriği $51.52 \mathrm{mg}$ rutin/g (Elfalleh vd., 2012) ve 18.61-36.40 mg catechin/g (Ardekani vd., 2011), elma ve kivi kabuklarının sirasiyla 10.15 ve $4.13 \mathrm{mg}$ quercetin/g (Afsharnezhad vd., 2017), domates kabuğunun ise $0.204 \mathrm{mg}$ rutin/g (Toor ve Savage, 2005) olarak bildirilmiştir. Sonuçlar karşılaştırıldığında, bu çalışmada bulunan elma, kivi, domates ve nar sonuçları literatür çalışmalarından daha yüksek bulunmuştur.

Tablo 4. Ekstraktların flavonoid içerikleri (mg KE/g)

\begin{tabular}{lcccc}
\hline & \% & \% 25 & \%50 & \% 75 \\
\hline Kivi & $3.03 \pm 0.08^{\mathrm{dC}}$ & $6.11 \pm 0.10^{\mathrm{CA}}$ & $5.89 \pm 0.02^{\mathrm{CA}}$ & $4.91 \pm 0.12^{\mathrm{dB}}$ \\
Kavun & $4.62 \pm 0.04^{\mathrm{CC}}$ & $5.11 \pm 0.08^{\mathrm{dB}}$ & $5.14 \pm .0 .01^{\mathrm{dB}}$ & $6.07 \pm 0.08^{\mathrm{cA}}$ \\
Domates & $2.16 \pm 0.01^{\mathrm{dD}}$ & $2.61 \pm 0.00^{\mathrm{eC}}$ & $3.74 \pm 0.10^{\mathrm{eB}}$ & $5.08 \pm 0.03^{\mathrm{dA}}$ \\
Elma & $6.56 \pm 0.15^{\mathrm{bC}}$ & $11.07 \pm 0.17^{\mathrm{bB}}$ & $13.31 \pm 0.14^{\mathrm{bA}}$ & $11.00 \pm 0.10^{\mathrm{bB}}$ \\
Ayva & $6.35 \pm 0.09^{\mathrm{bC}}$ & $11.35 \pm 0.06^{\mathrm{bB}}$ & $13.38 \pm 0.17^{\mathrm{bA}}$ & $11.14 \pm 0.18^{\mathrm{bB}}$ \\
Nar & $70.33 \pm 0.88^{\mathrm{aC}}$ & $76.74 \pm 0.20^{\mathrm{aA}}$ & $77.47 \pm 0.15^{\mathrm{aA}}$ & $73.50 \pm 0.10^{\mathrm{aB}}$ \\
\hline
\end{tabular}

Duncan testine göre aynı sütunda farklı harflerle $\left({ }^{\mathrm{a}, \mathrm{b}, \mathrm{c}, \mathrm{d}, \mathrm{e}, \mathrm{f}}\right)$ ve aynı satırda farklı harflerle $\left({ }^{\mathrm{A}, \mathrm{B}, \mathrm{C}, \mathrm{D}}\right)$ belirtilmiş ortalamalar birbirinden farklı $(\mathrm{p}<0.05)$ olup, değerler 3 paralelin ortalaması ve standart sapma olarak ifade edilmiştir.

Tablo 5'te ekstraktların toplam monomerik antosiyanin içerikleri verilmiş olup, etanol konsantrasyonunun artmasının, monomerik antosiyanin ekstraksiyonunu olumsuz etkilediği, etanol konsantrasyonları arasinda kivi (\%25) ve nar $(\% 25)$ haricinde diğer kabuklar için optimum etanol konsantrasyonun $\% 0$ olduğu görülmektedir. Kabuklar arasında fenolik ve flavonoid içeriğine benzer şekilde en yüksek monomerik antosiyanin içeriğine nar kabuğunun sahip olduğu, bunu sırasıyla kavun ve elmanın takip ettiği belirlenmiştir. Daha önce literatürde yapılan çalışmalar incelendiğinde, dört farklı elma kabuğunun toplam monomerik antosiyanin içerikleri 21-268 $\mu \mathrm{g} / \mathrm{g}$ (Wolfe vd., 2003), başka bir çalışmada ise $430 \mu \mathrm{g} / \mathrm{g}$ (Afsharnezhad vd., 2017), 10 farklı nar türünün kabuklarında 3.95-
$29.53 \mathrm{mg} / \mathrm{g}$ (Khanavi vd., 2013), kivi kabuklarında $0.116 \mathrm{mg} / \mathrm{g}$ (Afsharnezhad vd., 2017) olarak bildirilmiştir. Sonuçlar karşılaştırıldığında, elma ve kivi kabuklarının toplam manomerik antosiyanin içerikleri çalışmamızda $\% 0$ etanol konsantrasyonunda bulunan sonuçtan daha düşük olduğu, nar kabuklarının ise daha yüksek olduğu görülmektedir.

Meyve-sebze kabuk ekstraktlarının içerdikleri diğer fitokimyasallar bileşikler kalitatif olarak taranmış ve sonuçlar Tablo 6'da sunulmuştur. İncelenen ekstraktlar arasında nar kabuğu ekstraktının tanen içerdiği, diğer kabuk ekstraktlarının ise içermediği bulunmuştur. 
Tablo 5. Ekstraktların toplam monomerik antosiyanin içerikleri $(\mu \mathrm{g} / \mathrm{g})$

\begin{tabular}{lcccc}
\hline & \% & \%25 & \%50 & \% 75 \\
\hline Kivi & $165.05 \pm 2.81^{\mathrm{fB}}$ & $214.77 \pm 5.62^{\mathrm{cA}}$ & $61.65 \pm 2.81^{\mathrm{bC}}$ & $23.86 \pm 0.00^{\mathrm{dD}}$ \\
Kavun & $652.25 \pm 5.62^{\mathrm{bA}}$ & $385.78 \pm 11.25^{\mathrm{bB}}$ & $33.81 \pm 2.81^{\mathrm{cC}}$ & $7.95 \pm 0.00^{\mathrm{eD}}$ \\
Domates & $284.36 \pm 8.44^{\mathrm{eA}}$ & $41.76 \pm 2.81^{\mathrm{eC}}$ & $27.84 \pm 0.00^{\mathrm{cC}}$ & $95.45 \pm 5.62^{\mathrm{bB}}$ \\
Elma & $610.49 \pm 2.81^{\mathrm{cA}}$ & $69.60 \pm 2.81^{\mathrm{dB}}$ & $31.82 \pm 0.00^{\mathrm{cC}}$ & $15.91 \pm 0.00^{\mathrm{deD}}$ \\
Ayva & $548.84 \pm 0.00^{\mathrm{dA}}$ & $51.70 \pm 0.00^{\mathrm{eB}}$ & $29.83 \pm 2.81^{\mathrm{cD}}$ & $43.75 \pm 5.62^{\mathrm{cC}}$ \\
Nar & $942.58 \pm 5.62^{\mathrm{aD}}$ & $1499.38 \pm 5.62^{\mathrm{aA}}$ & $1181.21 \pm 5.62^{\mathrm{aB}}$ & $970.42 \pm 5.60^{\mathrm{aC}}$ \\
\hline
\end{tabular}

Duncan testine göre aynı sütunda farklı harflerle $\left({ }^{\mathrm{a}, \mathrm{b}, \mathrm{c}, \mathrm{d}, \mathrm{e}, \mathrm{I}}\right)$ ve aynı satırda farklı harflerle ${ }^{\mathrm{A}, \mathrm{B}, \mathrm{C}, \mathrm{D})}$ ) belirtilmiş ortalamalar birbirinden farklı $(\mathrm{p}<0.05)$ olup, değerler 3 paralelin ortalaması ve standart sapma olarak ifade edilmiştir.

Antikanser, antiviral, antifungal, antibakteriyal, antitümör ve sitotoksik aktiviteye sahip kinon bileşiklerinin (Dongmo vd., 2015) tüm meyvesebze ekstraktlarında bulunduğu, kinon ve türevleri organik çözücülerde suya oranla daha iyi çözündüğ̈̈nden (Tanaka ve Toda, 2000), artan etanol konstrasyonunun kinon ekstraksiyonunu arttırdığı gözlemlenmiştir. Artan etanol konsantrasyonunun kardiyak glikozit ekstraksiyonunu da arttırdığı ve en yüksek içeriğe $\% 75$ etanol konsatrasyonunda nar, elma ve ayva kabuğu ekstraktlarında gözlenmiştir. Domates ve kavun kabuğu ekstraktlarında ise diğer ekstraktlara kıyasla daha az olduğu görülmektedir. Nar ekstraktlarında terpenoid, meyve-sebze ekstraktlarının tamamında ise kumarin varlığı tespit edilmiştir.

Tablo 6. Ekstraktların kalitatif analiz sonuçları

\begin{tabular}{|c|c|c|c|c|c|c|c|}
\hline & Ekstrakt & Tanen & Kinon & K.Glikozit & Terpenoid & Kumarin & Saponin \\
\hline \multirow[t]{4}{*}{ Kivi } & $0 \%$ & - & + & - & - & - & - \\
\hline & $25 \%$ & - & +++++ & - & - & + & - \\
\hline & $50 \%$ & - & ++++++ & + & - & + & - \\
\hline & $75 \%$ & - & ++++++ & ++ & - & + & - \\
\hline \multirow[t]{4}{*}{ Kavun } & $0 \%$ & - & + & - & - & + & - \\
\hline & $25 \%$ & - & ++ & - & - & ++ & - \\
\hline & $50 \%$ & - & ++++ & - & - & ++ & - \\
\hline & $75 \%$ & - & ++++++ & + & - & ++ & - \\
\hline \multirow[t]{4}{*}{ Domates } & $0 \%$ & - & ++ & - & - & + & - \\
\hline & $25 \%$ & - & +++ & - & - & ++ & - \\
\hline & $50 \%$ & - & ++++ & - & - & ++ & - \\
\hline & $75 \%$ & - & ++++++ & + & - & ++ & - \\
\hline \multirow[t]{4}{*}{ Elma } & $0 \%$ & - & +++ & + & - & ++ & - \\
\hline & $25 \%$ & - & ++++++ & ++ & - & ++ & - \\
\hline & $50 \%$ & - & ++++++ & +++ & - & ++ & - \\
\hline & $75 \%$ & - & ++++++ & +++ & - & ++ & - \\
\hline \multirow[t]{4}{*}{ Ayva } & $0 \%$ & - & ++++ & + & - & + & - \\
\hline & $25 \%$ & - & ++++++ & ++ & - & ++ & - \\
\hline & $50 \%$ & - & ++++++ & +++ & - & ++ & - \\
\hline & $75 \%$ & - & ++++++ & +++ & - & ++ & - \\
\hline \multirow[t]{4}{*}{ Nar } & $0 \%$ & + & ++++ & ++ & + & ++ & - \\
\hline & $25 \%$ & + & ++++++ & +++ & + & ++ & - \\
\hline & $50 \%$ & + & ++++++ & +++ & + & ++ & - \\
\hline & $75 \%$ & + & ++++++ & +++ & + & ++ & - \\
\hline
\end{tabular}

-: içermiyor, +: içeriyor (+ sayısının artışı, incelenen madde miktarınının kalitatif olarak daha fazla olduğunu ifade etmektedir) 
Gidaların antioksidan kapasitelerin değerlendirilmesi amaciyla birden fazla yöntem kullanılmaktadır (Song vd., 2010). Kabuk ekstraktlarının TEAC yöntemine göre belirlenen antioksidan kapasitesi karşılaştırıldığında; bir dereceye kadar artan etanol konsantrasyonunun antioksidan maddelerin ekstraksiyonunu arttırdığı, bu dereceden sonra azaldığ 1 gözlenmiştir (Tablo 7). Tüm ekstraksiyon koşullarında nar kabuk ekstraktlarının diğer ekstraktlara kıyasla oldukça yüksek antioksidan kapasiteye, en düşük değere ise sirasiyla kavun ve domates kabuk ekstraktlarının sahip olduğu belirlenmiştir. Ekstraktların FRAP ve DPPH yöntemine göre belirlenen antioksidan kapasiteleri TEAC yöntemi ile bulunan sonuçlara benzer şekilde en yüksek nar, en düşük ise domates ve kavun kabuk ekstraktlarının olduğu saptanmıştır (Tablo 7). İncelenen meyve-sebze kabukları arasında nar kabuğunun antioksidan aktivitesini, ayva ve elma kabuklarının izlediği saptanmıştır. Etanol konsantrasyonları karşılaştırıldığında ise, \%25 ve $\% 50$ etanol konsantrasyonlarının antioksidan maddeleri ekstrakte etmek için daha iyi olduğu görülmüştür. Kabukların fenolik madde ve flavonoid madde ekstraksiyonlarının da benzer şekilde $\% 25$ ve $\% 50$ etanol konsantrasyonunda daha yüksek olması, kabukların fenolik ve flavonoid içerikleri ile antioksidan kapasitesi arasındaki ilişkiyi de göstermektedir. Daha önceki çalışmalar incelendiğinde nar kabuğunun antioksidan kapasitesinin [(351.36-595.71 $\mu \mathrm{mol}$ TE/g-DPPH), (871.73-1056.34 $\mu \mathrm{mol} \quad \mathrm{TE} / \mathrm{g}-$ TEAC) (Marchi vd., 2015), (21.24-29.80 mmol TE/100g-FRAP) (Elfalleh vd., 2012) ve (3.80$7.50 \mathrm{mmol} / 100 \mathrm{~g}$-TEAC) (Elfalleh vd., 2012)] sonuçların çalışmamızda bulunan değerlerden daha düşük olduğu belirlenmiştir. Deng vd. (2012) tarafından kırmızı ve yeşil elma, domates, kivi ve kavun kabuklarının FRAP yöntemine göre belirlenen antioksidan kapasitesi sirasiyla 10.46, $11.33,5.06,15.90$ ve $13.05 \mu \mathrm{mol} \mathrm{Fe}(\mathrm{II}) / \mathrm{g}$ (FRAP) ve $14.89,15.49,6.35,20.63$ ve $7.01 \mu \mathrm{mol} \mathrm{TE} / \mathrm{g}$ (TEAC) olarak bildirilmiş olup, antioksidan kapasitelerin bu çalışmada bulunandan daha düşük olduğu belirlenmiştir. Literatür çalışmalarında, antioksidan madde ekstraksiyonu için kullanılan en uygun etanol konsantrasyonlarının ise meyve-sebze çeşitlerine göre farklılık gösterdiği saptanmıştır. Örneğin bu oran limon kabukları (Diankov vd., 2011) için \%50, rambutan kabukları (Samuagam vd., 2013) için \%40, mangostan ve langsat kabukları (Samuagam vd., 2013) için \%80 ve çarkıfelek meyvesi (Wang vd., 2014) ile boğadikeni (Hijazi vd., 2015) için ise \%40 etanol konsantrasyonu olarak bildirilmiştir.

Tablo 7. Ekstraktların antioksidan kapasiteleri ( $\mu \mathrm{mol} \mathrm{TE} / \mathrm{g})$

\begin{tabular}{|c|c|c|c|c|}
\hline & $\% 0$ & $\% 25$ & $\% 50$ & $\% 75$ \\
\hline \multicolumn{5}{|l|}{ TEAC } \\
\hline Kivi & $31.25 \pm 0.17^{\mathrm{bcdD}}$ & $67.52 \pm 1.48^{\mathrm{cA}}$ & $58.27 \pm 0.63^{\mathrm{cdB}}$ & $53.19 \pm 0.63^{\mathrm{cC}}$ \\
\hline Kavun & $17.56 \pm 0.13^{\mathrm{cdC}}$ & $25.21 \pm 0.30^{\mathrm{dB}}$ & $28.10 \pm 0.08^{\mathrm{eA}}$ & $24.88 \pm 0.34^{\mathrm{dB}}$ \\
\hline Domates & $13.59 \pm 0.00^{\mathrm{dC}}$ & $20.37 \pm 0.21^{\mathrm{dB}}$ & $33.16 \pm 1.01^{\mathrm{deA}}$ & $21.74 \pm 0.38^{\mathrm{dB}}$ \\
\hline Elma & $60.66 \pm 1.90^{\mathrm{bD}}$ & $125.43 \pm 1.90^{\mathrm{bB}}$ & $146.78 \pm 1.69^{\mathrm{bA}}$ & $101.85 \pm 0.21^{\mathrm{bC}}$ \\
\hline Ayva & $49.91 \pm 1.06^{\mathrm{bcD}}$ & $119.16 \pm 1.06^{\mathrm{bB}}$ & $140.96 \pm 1.06^{\mathrm{bA}}$ & $83.34 \pm 0.21^{\mathrm{bC}}$ \\
\hline Nar & $1822.39 \pm 36.94^{\mathrm{aC}}$ & $2020.15 \pm 31.66^{\mathrm{aB}}$ & $2355.97 \pm 31.66^{\mathrm{aA}}$ & $1527.61 \pm 21.11^{\mathrm{aD}}$ \\
\hline \multicolumn{5}{|l|}{ FRAP } \\
\hline Kivi & $23.23 \pm 0.66^{\mathrm{cC}}$ & $42.35 \pm 1.26^{\mathrm{cA}}$ & $37.59 \pm 0.30^{\mathrm{dB}}$ & $23.53 \pm 0.48^{\mathrm{cC}}$ \\
\hline Kavun & $26.33 \pm 0.12^{\mathrm{cB}}$ & $29.90 \pm 0.12^{\mathrm{cdA}}$ & $27.14 \pm 0.54^{\mathrm{eB}}$ & $22.59 \pm 1.20^{\mathrm{cC}}$ \\
\hline Domates & $19.28 \pm 1.32^{\mathrm{cB}}$ & $22.68 \pm 0.96^{\mathrm{dA}}$ & $23.74 \pm 0.66^{\mathrm{fA}}$ & $15.92 \pm 0.18^{\mathrm{cC}}$ \\
\hline Elma & $43.28 \pm 1.74^{\mathrm{bC}}$ & $82.62 \pm 2.70^{\mathrm{bA}}$ & $83.98 \pm 1.50^{\mathrm{cA}}$ & $63.42 \pm 0.18^{\mathrm{bB}}$ \\
\hline Ayva & $49.10 \pm 1.20^{\mathrm{bC}}$ & $84.96 \pm 2.40^{\mathrm{bA}}$ & $88.19 \pm 0.84^{\mathrm{bA}}$ & $65.84 \pm 1.08^{\mathrm{bB}}$ \\
\hline Nar & $1024.71 \pm 7.5^{\mathrm{aA}}$ & $1019.40 \pm 18.02^{\mathrm{aA}}$ & $963.10 \pm 1.50^{\mathrm{aB}}$ & $855.83 \pm 15.02^{\mathrm{aC}}$ \\
\hline \multicolumn{5}{|l|}{ DPPH } \\
\hline Kivi & $13.12 \pm 0.10^{\mathrm{cD}}$ & $25.62 \pm 0.68^{\mathrm{dB}}$ & $31.01 \pm 0.26^{\mathrm{cA}}$ & $18.84 \pm 0.26^{\mathrm{cC}}$ \\
\hline Kavun & $9.36 \pm 0.10^{\mathrm{cD}}$ & $11.43 \pm 0.21^{\mathrm{eC}}$ & $14.60 \pm 0.63^{\mathrm{dA}}$ & $12.68 \pm 0.10^{\mathrm{cB}}$ \\
\hline Domates & $6.82 \pm 0.26^{\mathrm{cC}}$ & $10.10 \pm 0.21^{\mathrm{eB}}$ & $13.75 \pm 0.26^{\mathrm{dA}}$ & $12.61 \pm 1.77^{\mathrm{cAB}}$ \\
\hline Elma & $40.19 \pm 0.30^{\mathrm{bD}}$ & $77.06 \pm 1.36^{\mathrm{cB}}$ & $87.39 \pm 0.31^{\mathrm{bA}}$ & $63.27 \pm 1.25^{\mathrm{bC}}$ \\
\hline Ayva & $39.12 \pm 0.47^{b D}$ & $83.78 \pm 0.83^{\mathrm{bB}}$ & $96.61 \pm 0.63^{\mathrm{bA}}$ & $71.02 \pm 1.77^{\mathrm{bC}}$ \\
\hline Nar & $1250.03 \pm 18.25^{\mathrm{aB}}$ & $1306.27 \pm 3.91^{\mathrm{aA}}$ & $1233.43 \pm 13.0^{\mathrm{aB}}$ & $1127.40 \pm 14.34^{\mathrm{aC}}$ \\
\hline
\end{tabular}

Duncan testine göre aynı sütunda farklı harflerle $\left({ }^{\mathrm{a}, \mathrm{b}, \mathrm{c}, \mathrm{d}, \mathrm{e}, \mathrm{f}}\right)$ ve aynı satırda farklı harflerle ${ }^{\mathrm{A}, \mathrm{B}, \mathrm{C}, \mathrm{D}}$ ) belirtilmiş ortalamalar birbirinden farklı $(\mathrm{p}<0.05)$ olup, değerler 3 paralelin ortalaması ve standart sapma olarak ifade edilmiştir. 


\section{Sonuç}

$\mathrm{Bu}$ çalışmada, önemli bir ekonomik değeri olmayan kabuk gibi meyve-sebze atıklarının, gida ve diğer endüstri kollarında kullanılabilecek, katma değeri yüksek fitokimyasal bileşikler için önemli bir kaynak olduğu gösterilmiştir. Kabuklar arasında, nar kabuğunun antosiyanin, flavonoid, fenolik madde içeriği ve antioksidan kapasitesi açısından diğer kabuklara kıyasla oldukça yüksek olduğu, bunu ayva ve elma kabuğunun takip ettiği saptanmıştır. Fenolik maddelerin ekstraksiyonunu için $\% 25$ ve $\% 50$ etanol konsantrasyonlarının, diğer konsantrasyonlara göre daha başarılı olduğu bulunmuştur. $\mathrm{Bu}$ çalışma sonucunda ekonomik değeri düşük olan çeşitli meyve-sebze kabuklarının, hem de gida ve diğer sanayi kollarında değerlendirilebilir forma dönüştürülerek ekonomik fayda sağlanabileceği sonucuna ulaşılmıştır. Çalışmanın sonuçları endüstriyel boyuta taşındığında, atıkların daha uygun bir şekilde ortadan kaldırılması, çevresel problemlerin önüne geçilmesi ve farklı alanlarda istihdam ve kalkınmaya destek sağlanabilmesi gibi ülke ekonomisine de katkısı olabilecektir.

\section{Kaynaklar}

Acquistucci, R., Bucci, R., Magri, A.D. ve Magri, A.R., 1991. Evaluation of the moisture and ash contents in wheat mills by multistep programmed thermogravimetry. Thermochimica Acta, 188(1), 51-62.

Afsharnezhad, M., Shahangian, S.S., Panahi, E. ve Sariri, R., 2017. Evaluation of the antioxidant activity of extracts from some fruit peels. Caspian Journal of Environmental Sciences, 15(3), 213-222.

Ahamad, M.N., Saleemullah, M., Shah, H.U., Khalil, I.A. ve Saljoqi, A.U.R., 2007. Determination of beta carotene content in fresh vegetables using high performance liquid chromatography. Sarhad Journal of Agriculture, 23(3), 767-770.

Ardekani, M.R.S., Hajimahmoodi, M., Oveisi, M.R., Sadeghi, N., Jannat, B., Ranjbar, A.M., Gholam, N. ve Moridi, T., 2011. Comparative antioxidant activity and total flavonoid content of persian pomegranate (Punica granatum 1.) Cultivars. Iranian Journal of Pharmaceutical Research, 10, 519-524.

AOAC, 1989. Officials Methods of Analysis. 15th Edition, Washington DC, the USA.

Ashoush, I.S. ve Gadallah, M.G.E., 2011. Utilization of mango peels and seed kernels powders as sources of phytochemicals in biscuit. World Journal of Dairy \& Food Sciences, 6 (1), 35-42.
Balch, J.F. ve Balch, P.A., 1997. Prescription for nutritional healing. 2nd Edition, Avery Publishing Group, Garden City Park, New York.

Benzie, I.F.F. ve Strain, J.J., 1996. The ferric reducing ability of plasma (FRAP) as a measure of "antioxidant power": The FRAP assay. Analytical Biochemistry, 239, 70-76.

Brand-Williams, W., Cuvelier, M. ve Berset, C., 1995. Use of free radical method to evaluate antioxidant activity. Food Science and Technology, 28, 25-30.

Cam, M. ve Aaby, K., 2010. Optimization of extraction of apple pomace phenolics with water by response surface methodology, Journal of Agricultural and Food Chemistry, 58, 91019111.

Canan, İ., Gündoğdu, M., Seday, U., Oluk, C.A., Karaşahin, Z., Eroğlu, Ç.E., Yazıcı, E. ve Ünlü, M., 2016. Determination of antioxidant, total phenolic, total carotenoid, lycopene, ascorbic acid and sugar contents of Citrus species and mandarin hybrids. Turkish Journal of Agriculture and Forestry, 40, 894-899.

Cemeroğlu, B., 2010. Gida Analizleri. Gida Teknolojisi Derneği Yayınları, No:34, 480 s., Ankara.

Deng, G.F., Shen, C., Xu, X.R., Kuang, R.D., Guo, Y.J., Zeng, L.S., Gao, L.L., Lin, X., Xie, J.F., Xia, E.Q., Li, S., Wu, S., Chen, F.,Ling, W.H. ve $\mathrm{Li}, \mathrm{H}$. B., 2012. Potential of fruit wastes as natural resources of bioactive compounds. International Journal of Molecular Sciences, 13(7), 8308-8323.

Deschner, E.E., Ruperto, J., Wong, G. ve Newmark, H.L., 1991. Quercetin and rutin as inhibitors of azoxymethanol-induced colonic neoplasia. Carcinogenesis, 7, 1193-1198.

Diankov, S., Karsheva, M. ve Hinkov, I., 2011. Extraction of natural antioxidants from lemon peels. Kinetics and antioxidant capacity. Journal of the University of Chemical Technology and Metallurgy, 46(3), 315-319.

Dongmo, S., Witt, J. ve Wittstock, G., 2015. Electropolymerization of quinone-polymers onto grafted quinone monolayers: a route towards non-passivating, catalytically active film. Electrochimica Acta, 155, 474-482.

Dündar, Y., 2001. Fitokimyasallar ve sağlıklı yaşam. Kocatepe Tip Dergisi. 2, 131-138.

Elfalleh, W., Hannachi, H., Tlili, N., Yahia, Y., Nasri, N. ve Ferchichi, A., 2012. Total phenolic contents and antioxidant activities of 
pomegranate peel, seed, leaf and flower. Journal of Medicinal Plants Research, 6, 4724-4730.

FAO, 2017. The Food and Agriculture Organization. http://www.fao.org/faostat/en/\#rankings/countri es_by_commodity (12.12. 2018).

Fernandez-Panchon, M.S., Villano, D., Troncoso, A.M. ve Garcia-Parrilla, M.C., 2008. Antioxidant activity of phenolic compounds: From in vitro results to in vivo evidence. Critical Reviews in Food Science and Nutrition, 48, 649- 671.

Fidrianny, I., Harnovi, M. ve Insanu, M., 2014. Evaluation of antioxidant activities from various extracts of sweet orange peels using dpph, frap assays and correlation with phenolic, flavonoid, carotenoid content. Asian Journal of Pharmaceutical and Clinical Research, 7(3),186190.

Friedman, M. ve Levin, C., 2009. Analysis and biological activities of potato glycoalkaloids, calystegine alkaloids, phenolic compounds and anthocyanins. In J. Singh, \& L. Kaur (Eds.) Advances in Potato Chemistry and Technology, pp. 127-161.

Fuleki, T. ve Francis, F., 1968. Quantitative methods for anthocyanins. Journal of Food Science, 33, 72-77.

Garcia, E.M. ve Barret, D., 2005. Assessing lycopene content in California processing tomatoes. Journal of Food Processing and Preservation, 30, 56-70.

George, B., Kaur, C., Khurdiya, D.S. ve Kapoor, H.C., 2004. Antioxidants in tomato (Lycopersium esculentum) as a function of genotype. Food Chemistry, 84, 45-51.

Ghasemi, K., Ghasemi, Y. ve Ebrahimzadeh, M.A., 2009. Antioxidant activity, phenol and flavonoid contents of 13 citrus species peels and tissues. Pakistan Journal of Pharmaceutical Sciences, 22(3), 277-281.

Gorinstein, S., Zachwieja, Z., Katrich, E., Pawelzik, E., Haruenkit, R., Trakhtenberg, S. ve MartinBelloso, O., 2004. Comparison of the contents of the main antioxidant compounds and the antioxidant activity of white grapefruit and his new hybrid. LWT- Food Science and Technology, 37, 337-343.

Güney, O., Canbilen, A., Konak, A. ve Acar, O., 2003. The effects of folic acid in the prevention of neural tube development defects caused by phenytoin in early chick embryos. Spine, 28(5), $442-445$.

Haslam, E., 1998. Practical polyphenolics from structure to molecular recognition and physiological action. Cambridge University Press, Cambridge, UK.

Henríquez, C., Almonacid, S., Chiffelle, I., Valenzuela, T., Araya, M., Cabezas, L. ve Speisky, H., 2010. Determination of antioxidant capacity, total phenolic content and mineral composition of different fruit tissue of five apple cultivars grown in Chile. Chilean Journal of Agricultural Research, 70(4), 523-536.

Hışıl, 2004. Enstrümental gıda analizleri-laboratuar deneyleri. Ege Üniversitesi Mühendislik Fakültesi Ders Kitapları Yayın no:45, Bornova, İzmir.

Hijazi, A., Al Masri, D.S., Farhan, H., Nasser, M., Rammal, H. ve Annan, H., 2015. Journal of Pharmaceutical, Chemical and Biological Sciences, 3(2), 262-271.

Holden, J.M., Eldridge, A.L., Beecher, G.R., Buzzard, I.M., Bhagwat, S., Davis, C.S., Douglass, L.W., Gebhardt, S., Haytowitz, D. ve Schakel, S., 1999. Carotenoid content of US foods: an update of the database. Journal of Food Composition and Analysis, 12, 169-196.

İnanır, C., Albayrak, S. ve Ekici, L., 2019. Karabuğdayın fitokimyası, farmakolojisi ve biyofonksiyonel özellikleri. Avrupa Bilim ve Teknoloji Dergisi, 16, 713-722.

Janarthanan, U.K., Varadharajan, V. ve Krishnamurthy, V., 2012. Physicochemical evaluation, phytochemical screening and chromatographic fingerprint profile of Aegle marmelos (L.) leaf extracts. World Journal of Pharmaceutical Research, 1(3), 813-837.

Khanavi, M., Moghaddam, G., Oveisi, M. R., Sadeghi, N., Jannat, B., Rostami, M., Saadat, M. A. ve Hajimahmoodi, M., 2013. Hyperoside and anthocyanin content of ten different pomegranate cultivars. Pakistan Journal of Biological Sciences, 16(13), 636-641.

Kırışoğlu, S. ve Velioğlu, S., 2001. Hiper besleyici gidalar. Bilim Teknik Dergisi, 4, 56-57.

Koca, N. ve Karadeniz, F., 2005. Gıdalardaki doğal antioksidan bileşikler. Gıda, 30(4), 229-236.

Larson, R. A., 1988. The antioxidants of higher plants. Phytochemistry, 27(4), 969-978.

Larson, R.A., 1997. Naturally Occurring Antioxidants. Boca Raton, Lewis Publishers, 202p., Newyork.

Li, Y., Ma, D., Sun, D., Wang, C., Zhang, J., Xie, Y. ve Guo, T., 2015. Total phenolic, flavonoid content, and antioxidant activity of flour, noodles, and steamed bread made from different 
colored wheat grains by three milling methods. The Crop Journal, 3, 328-334.

Lim, Y.Y., Lim, T.T. ve Tee, J.J., 2006. Antioxidant properties of guava fruit: comparison with some local fruits. Sunway Academic Journal, 3, 9-20.

Marchi, L.B., Monteiro, A.R., Mikcha, J., Santos, A., Chinelatto, M., Marques, D., Dacome, A.S. ve Costa, S.C., 2015. Evaluation of antioxidant and antimicrobial capacity of pomegranate peel extract (Punica granatuml.) Under different drying temperatures. Chemical Engineering Transactions, 44, 121-126.

Melo, E.A., De Lima, V.L.A.G., Maciel, M.I.S., Caetano, A.C.S. ve Leal, F.L.L., 2006. Polyphenol, ascorbic acid and total carotenoid contents in common fruits and vegetables. Brazilian Journal of Food Technology, 9(2), 8994.

Morais, D.R., Rotta, E.M., Sargi, S.C., Bonafe, E.G., Suzuki, R.M., Souza, N.E., Matsushita, M. ve Visentainer, J.V., 2017. Proximate composition, mineral contents and fatty acid composition of the different parts and dried peels of tropical fruits cultivated in Brazil. Journal of the Brazilian Chemical Society, 28(2), 308-318.

Moroney, M. A., Alcanaz, M. J., Forder, R. A., Carey, F. ve Hoult, J.R.S., 1988. Selectivity of neutrophil 5-lipoxygenase and cyclo-oxygenase inhibition by an antiinflammatory flavonoid glycoside and related aglycone flavonoids. Journal of Pharmacy and Pharmacology, 40, 787-791.

Nizamlıŏlu, M.N. ve Nas, S., 2010. Meyve ve sebzelerde bulunan fenolik bileşikler yapıları ve önemleri. Gıda Teknolojileri Elektronik Dergisi, 1(5), 20-35.

Okiei, W., Ogunles, M., Azeez, L., Obakachi, V., Osunsami, M. ve Nkenchor, G., 2009. The voltammetric and titrimetric determination of ascorbic acid levels in tropical fruit samples. International Journal of Electrochemical Science, 4, 276-287.

Paula, J.T., Paviani, L.C., Foglio, M.A., Sousa, I.M.O., Duarte, G.H.B., Jorge, M.P., Eberlin, M.N. ve Cabral, F.A., 2014. Extraction of anthocyanins and luteolin from Arrabidaea chica by sequential extraction in fixed bed using supercritical $\mathrm{CO} 2$, ethanol and water as solvents. The Journal of Supercritical Fluids, 86,100-107.

Poli, A., Anzelmo, G., Fiorentino, G., Nicolaus, B., Tommonaro, G. ve Di Donato P., 2011. Polysaccharides from wastes of vegetable industrial processing: New opportunities for their eco-friendly re-use. Biotechnology of Biopolymers, 33-56.

Pratt, D.E. ve Hundson, B.J.F., 1990. Natural antioxidants not exploited commercially. Food Antioxidants, 171-191.

Re, R., Pellegrini, N., Proteggente, A., Pannala, A., Yang, M. ve Rice-Evans, C., 1999. Antioxidant activity applying an improved ABTS radical cation decolorization assay. Free Radical Biology and Medicine, 26, 1231-1237.

Romelle, F.D, Rani, P.A. ve Manohar, R.S., 2016. Chemical composition of some selected fruit peels. European Journal of Food Science and Technology, 4(4), 12-21.

Samuagam, L., Sia, C.M., Akowuah, G.A., Okechukwu, P.N. ve Yim, H.S., 2013. The effect of extraction conditions on total phenolic content and free radical scavenging capacity of selected tropical fruits'peel. Health and the Environment Journal, 4(2),80-102.

Sanusi, R.A. ve Adebiyi, A.E., 2009. Beta Carotene Content of Commonly Consumed Foods and Soups in Nigeria. Pakistan Journal of Nutrition, 8(9), 1512-1516.

Schiassi, M.C.E.V., de Souza, V.R., Lago, A.M.T., Campos, L.G. ve Queiroz, F., 2018. Fruits from the Brazilian Cerrado region: Physico-chemical characterization, bioactive compounds, antioxidant activities, and sensory evaluation. Food Chemistry, 245, 305-311.

Setiawan, B., Sulaeman, A., Giraud, D.W. ve Driskell, J.A., 2001. Carotenoid content of selected Indonesian fruits. Journal of Food Composition and Analysis, 14, 169-176.

Shrikhande, A.J., 2000. Wine by products with health benefits. Food Research International, 33, 469474.

Silva, B.M., Andrade, P.B., Valentão, P., Ferreres, F., Seabra, R.M. ve Ferreira, M.A., 2004. Quince (Cydonia oblonga Miller) fruit (pulp, peel, and seed) and jam: antioxidant activity. Journal of Agricultural and Food Chemistry, 52, 44054712.

Singh, S. ve Immanuel, G., 2014. Extraction of antioxidants from fruit peels and its utilization in paneer. $\mathrm{J}$ Food Processing Technology, 5,349 .

Singleton, V.L. ve Rossi, J.A., 1965. Colorimetry of total phenolics with phosphomolybdicphosphotungstic acid reagents. American Journal of Enology and Viticuture, 16, 144-158. 
Someya, S., Yoshiki, Y. ve Okubo, K., 2002. Antioxidant compounds from bananas (Musa cavendish). Journal of Food Chemistry, 79, 351354.

Song, F., Parekh, S., Hooper, L., Loke, Y.K., Ryder, J.J., Sutton, A.J., Hing, C., Kwok, C.S., Pang, C. ve Harvey, I.,2010. Dissemination and publication of research findings: an updated review of related biases. Health Technology Assessment, 14,8.

Souza, V.R., Pereira, P.A.P., Silva, T.L.T., Lima, L.C.O., Pio, R. ve Queiroz F., 2014. Determination of the bioactive compounds, antioxidant activity and chemical composition of Brazilian blackberry, red raspberry, strawberry, blueberry and sweet cherry fruits. Food Chemistry, 156, 362-368.

Tanaka, K. ve Toda, F., 2000. Solvent-free organic synthesis. Chemical Reviews, 100, 1025-1074.

TÜİK, 2018. Bitkisel Üretim İstatistikleri. http://www.tuik.gov.tr/VeriBilgi.do?alt_id=100 1 (12.03.2019).

Toor, R.K. ve Savage, G.P., 2005. Antioxidant activity in different fractions of tomatoes. Food Research International 38, 487-494.
URL-1, 2014. Fruit peel nutrition facts. http://www.nutrition-and-you.com/fruitpeel.html (19.10.2014).

Visioli, F., Borsani, L. ve Gali, C., 2000. Diet and prevention of coronary heart disease: the potential role of phytochemicals. Cardiovascular Research, 47, 149-425.

Wagner, H., Elbi, G., Lotter, H. ve Guinea, N., 1991. Evaluation of natural products as inhibitors of angiotensin iconverting enzyme (ACE). Pharmaceutical and Pharmacological Letters, 1, 15-18.

Wang, Y.C., Chuang, Y.C. ve Hsu, H.W., 2008. The flavonoid, carotenoid and pectin content in peels of citrus cultivated in Taiwan. Food Chemistry, 106, 277-284.

Waszkowiak, K. ve Swigło, A.G., 2016. Binary ethanol-water solvents affect phenolic profile and antioxidant capacity of flaxseed extracts. European Food Research and Technology, 242,777-786.

Wolfe, K., Wu, X. ve Liu, R.H., 2003. Antioxidant activity of apple peels. Journal of Agricultural and Food Chemistry, 51, 609-614. 